Jurnal Gizi dan Dietetik Indonesia

Vol. 5, No. 1, 2017: 23-30
Tersedia online pada: http://ejournal.almaata.ac.id/index.php/IJND

DOI : http://dx.doi.org/10.21927/ijnd.2017.5(1).23-30

\title{
Berat badan lahir rendah berhubungan dengan kejadian stunting pada anak usia 6-23 bulan
}

\author{
Yeyen Supriyanto ${ }^{1}$, Bunga Astria Paramashanti ${ }^{1}$, Dewi Astiti ${ }^{1}$ \\ 1Program Studi S1 IImu Gizi, Fakultas IImu-ilmu Kesehatan Universitas Alma Ata \\ Jl. Brawijaya 99 Yogyakarta, \\ e-mail: yeyensupriyanto02@gmail.com.
}

\begin{abstract}
ABSTRAK
Latar belakang: Stunting adalah gangguan pertumbuhan yang terjadi akibat kondisi kekurangan gizi kronis atau penyakit infeksi kronis. Dampak yang ditimbulkan antara lain lambatnya pertumbuhan anak, daya tahan tubuh yang rendah, kurang kecerdasan dan produktivitas yang rendah. Prevalensi balita stunting di Indonesia mencapai 37,2\%, sementara di Provinsi Daerah Istimewa Yogyakarta (DIY) sebesar 27\%, di Kabupaten Bantul sebesar 18,08\%. Bayi BBLR memiliki kesempatan hidup dan ketika bertahan mereka mudah terkena penyakit, retardasi pertumbuhan dan gangguan perkembangan mental. Statistik menunjukan bahwa 90\% dari kejadian BBLR didapatkan di negara berkembang dan angka kematian 35 kali lebih tinggi dibandingkan pada bayi dengan bayi berat badan lahir lebih dari 2.500 gram.

Tujuan: Untuk mengetahui hubungan antara BBLR dengan kejadian stunting pada anak usia 6-23 bulan di Kecamatan Sedayu Kabupaten Bantul Yogyakarta.

Metode: Penelitian ini merupakan penelitian observasional dengan rancangan cross sectional. Populasi dalam penelitian ini adalah orang tua dan anak yang berumur 6-23 bulan yang berjumlah 1217 responden. Sampel dalam penelitian ini berjumlah 190 yang diambil dengan teknik proporsional probability to size yaitu prosedur penarikan sampel dimana peluang terpilihnya suatu unit sampel sebanding dengan ukuran. Data yang telah dikumpulkan kemudian dianalisis menggunakan uji statistik chi-square.

Hasil: Berdasarkan analisis Chi-Square menunjukkan anak yang BBLR memiliki hubungan yang signifikan dengan kejadian stunting ( $p$ value $<0,000$ ) dengan nilai OR 6,16 (95\% Cl: 3,007-12,656), dengan kata lain anak yang lahir dengan berpeluang 6,16 kali lebih besar untuk mengalami stunting dari pada anak yang memiliki berat badan lahir normal.

Kesimpulan: Ada hubungan antara BBLR dengan kejadian stunting pada anak usia 6-23 bulan di Kecamatan Sedayu Kabupaten Bantul, Yogyakarta.
\end{abstract}

KATA KUNCI: stunting, berat badan bayi lahir rendah (BBLR), anak usia 6-23 bulan

\section{Low birth weight was associated with stunting in children aged 6-23 months}

\begin{abstract}
Background: Stunting is a growth impairment resulting from chronic malnutrition condition or prolonged infectious diseases. It may cause growth retardation, low endurance, lack of intelligence and productivity. Stunting prevalence in Indonesia reached 37.2\% where Special Region of Yogyakarta reached 27\% and Bantul District was $18.08 \%$. Low birth weight babies have a life chance, however, when they survive they are still vulnerable to diseases, growth retardation, and developmental disorders. Statistics showed that 90\% low birth weight cases found in developing countries and the mortality rate was 35 times higher in infants with low birth weight compared to infants with normal birth weight.

Objectives: To understand the relationship between weight low birth (BBLR) and stunting in children 6-23 month in Sedayu District Bantul Yogyakarta .

Methods: This study used observational research with cross-sectional design. The population in this study were parents and children from 6-23 months which were 1217 subjects. The sample used in this
\end{abstract}


study as many as 190 subjects were selected by using proportional probability to size techniques. Data were analyzed by using chi-square test.

Results: Bivariate analysis showed that low birth weight infants was significantly related with stunting $(O R=6.16 ; 95 \% \mathrm{Cl}$ : 3.007-12.656). In other words, children born with low birth weight status had a chance 6.16 times greater to become stunting than the children who birth weight normal

Conclusion: There was a relationship between low birth weight infants and stunting in children 6-23 months in Sedayu Subdistrict, Bantul District, Yogyakarta.

KEYWORDS: low birth weight, stunting, children aged 6-23 months

\section{PENDAHULUAN}

Stunting adalah gangguan pertumbuhan yang terjadi akibat kondisi kekurangan gizi kronis atau penyakit infeksi kronis (1). Berdasarkan peringkat dunia mengenai anak balita yang stunting, Indonesia menduduki peringkat ke-5 dengan prevalensi stunting sebesar $37 \%$ (2). Menurut data Riset kesehatan dasar tahun 2013, prevalensi stunting di Indonesia pada tahun 2013 sebesar $37,2 \%$ yang berarti mengalami peningkatan pada tahun 2010 yaitu $35,6 \%$. Prevalensi stunting di Provinsi Derah Istimewa Yogyakarta (DIY) pada tahun 2013 sebesar $27,3 \%$ (3). Prevalensi stunting di Kabupaten Bantul pada tahun 2012 sebesar 18,08 \% sedangkan prevalensi stunting balita di Kecamatan Sedayu sebesar $16,93 \%$ (4).

Faktor yang mempengaruhi stunting antara lain berat badan lahir rendah (BBLR), kekurangan energi protein, penyakit kronis, asupan makan yang kurang dan kurang jenis makanan, faktor kemiskinan dan pola asuh anak yang tidak memadai (2). Dampak yang ditimbulkan antara lain lambatnya pertumbuhan anak, daya tahan tubuh yang rendah, kurangnya kecerdasan dan produktifitas yang rendah (5).

BBLR adalah bayi lahir dengan berat badan kurang dari 2.500 gram tanpa melihat masa kehamilan. BBLR umumnya mengalami kehidupan masa depan yang kurang baik. Prevalensi BBLR tahun 2010 di Indonesia sebesar 8,8\%. Kejadian BBLR di DIY yaitu sebesar 3,36\% (6). Persentase bayi dengan BBLR pada tahun 2013 sebesar $3,5 \%$. Jumlah BBLR di Kabupaten Bantul 530 kasus $(5,09 \%)$ (4). Bayi BBLR tipe kecil masa kehamilan (dismatur) sejak dalam kandungan telah mengalami retardasi pertumbuhan intera uterin dan akan berlanjut sampai usia selanjutnya setelah dilahirkan yaitu mengalami pertumbuhan dan perkembangan yang lebih lambat dari bayi lahir normal, dan sering gagal menyusul tingkat pertumbuhan yang seharusnya dicapai pada usia setelah lahir (7). Hambatan pertumbuhan yang terjadi berkaitan dengan maturitas otak, dimana sebelum usia kehamilan 20 minggu terjadi hambatan pertumbuhan otak seperti perubahan somatik (8). Faktor risiko kejadian stunting pada baduta adalah riwayat BBLR. Menurut penelitian Nasution, anak dengan riwayat BBLR memiliki risiko lebih besar untuk mengalami stunting dibandingkan anak yang lahir dengan berat normal (5). Penelitian Lestari, dkk, di kota Subulussalam, Aceh juga menyebutkan BBLR merupakan faktor risiko terjadinya stunting (9). Bayi BBLR juga mengalami gangguan saluran pencernaan, karena saluran pencernaan belum berfungsi, seperti kurang dapat menyerap lemak dan mencerna protein sehingga mengakibatkan kurangnya cadangan zat gizi dalam tubuh(10).

Tujuan dari penelitian ini adalah untuk mengetahui hubungan BBLR dengan kejadian stunting pada anak usia 6-23 bulan di Kecamatan Sedayu Kabupaten Bantul Yogyakarta.

\section{BAHAN DAN METODE}

Jenis penelitian ini adalah penelitian observasional dengan rancangan cross-sectional. Penelitian ini merupakan bagian dari penelitian yang berjudul "Faktor-Faktor Risiko Kejadian Stunting pada Anak Usia 6-23 Bulan" yang salah satu luarannya telah diterbitkan di https://jurnal.ugm.ac.id/jgki/article/ view/15989/18602. Populasi dalam penelitian ini adalah orang tua dan anak yang berumur 6-23 bulan di Kecamatan Sedayu Kabupaten Bantul Yogyakarta 
yang berjumlah 1.217 baduta. Pengambilan sampel dalam penelitian ini menggunakan teknik proporsional probability to size yaitu suatu prosedur penarikan sampel dengan peluang terpilihnya suatu unit sampel sebanding dengan ukuran sampel yang sesuai dengan kriteria inklusi dan eksklusi. Jumlah sampel yang didapatkan dalam penelitian yaitu 190 responden.

Variabel independen penelitian ini yaitu BBLR, sedangkan variabel dependen yaitu stunting, BBLR diukur dengan observasional / melihat buku kesehatan ibu dan anak (KIA). Stunting diukur dengan menggunakan tabel WHO ANTRO 2005 dengan memasukkan panjang badan menurut umur (PB/U). Stunting adalah apabila panjang badan menurut umur kurang dari atau sama dengan minus 2 standar devisasi (11). BBLR adalah bayi lahir dengan berat badan kurang dari 2.500 gram tanpa melihat masa kehamilan (7). Analisis data menggunakan analisis univariat dan bivariat dengan uji chi-square.

\section{HASIL}

Berdasarkan Tabel 1 menunjukkan bahwa persentase stunting lebih tinggi pada kelompok responden berjenis kelamin perempuan yaitu sebanyak $35,1 \%$, sedangkan menurut usia persentase stunting yang lebih berisiko pada kelompok usia $18-23$ bulan yaitu sebanyak $52,2 \%$. Berdasarkan karakteristik usia ibu, persentase stunting anak yang berisiko lebih tinggi pada kelompok usia ibu 20-30 tahun yaitu sebayak $34,4 \%$, sedangkan persentase ibu dengan pendidikan rendah dan memiliki anak risiko stunting sebanyak $31,6 \%$ anak mengalami stunting. Pada karakteristik usia ayah, persentase stunting terdapat lebih tinggi pada kelompok responden yang berusia di antara 20-30 tahun memiliki anak mengalami kejadian stunting yaitu sebanyak $33,7 \%$, sedangkan persentase pendidikan ayah yang rendah berisiko memiliki anak stunting pada kelompok usia 20-30 tahun yaitu sebanyak $31,5 \%$, dan persentase ayah yang tidak bekerja berisiko memiliki anak stunting yaitu sebanyak $30,2 \%$.

Tabel 2 menunjukkan bahwa anak di Kecamatan Sedayu Kabupaten Bantul Yogyakarta
Tabel 1 Distribusi frekuensi berdasarkan karakteristik responden karakteristik responden di Kecamatan Sedayu Kabupaten Bantul Yogyakarta.

\begin{tabular}{|c|c|c|c|c|c|c|}
\hline \multirow{3}{*}{$\begin{array}{l}\text { Karakteristik } \\
\text { responden }\end{array}$} & \multicolumn{4}{|c|}{ Kejadian stunting } & \multirow{2}{*}{\multicolumn{2}{|c|}{ Total }} \\
\hline & \multicolumn{2}{|c|}{ Stunting } & \multicolumn{2}{|c|}{$\begin{array}{c}\text { Tidak } \\
\text { stunting }\end{array}$} & & \\
\hline & $\mathbf{n}$ & $\%$ & $\mathrm{n}$ & $\%$ & $\mathbf{n}$ & $\%$ \\
\hline \multicolumn{7}{|l|}{ Jenis kelamin } \\
\hline Laki laki & 30 & 26,5 & 83 & 73,5 & 113 & 100 \\
\hline Perempuan & 27 & 35,1 & 50 & 64,9 & 77 & 100 \\
\hline \multicolumn{7}{|l|}{ Usia anak } \\
\hline 6-11 bulan & 12 & 19,7 & 49 & 80,3 & 61 & 100 \\
\hline $12-17$ bulan & 11 & 17,7 & 51 & 82,3 & 62 & 100 \\
\hline $18-23$ bulan & 35 & 52,2 & 32 & 47,8 & 67 & 100 \\
\hline \multicolumn{7}{|l|}{ Usia ibu } \\
\hline 20-30 tahun & 42 & 34,4 & 80 & 65,6 & 112 & 100 \\
\hline $31-40$ tahun & 15 & 22,1 & 53 & 77,9 & 68 & 100 \\
\hline \multicolumn{7}{|l|}{ Pendidikan ibu } \\
\hline Rendah & 21 & 30,4 & 48 & 69,6 & 69 & 100 \\
\hline Tinggi & 36 & 29,8 & 85 & 70,2 & 121 & 100 \\
\hline \multicolumn{7}{|l|}{ Pekerjaan ibu } \\
\hline Bekerja & 21 & 27,6 & 55 & 72,4 & 76 & 100 \\
\hline Tidak bekerja & 36 & 31,6 & 78 & 68,4 & 114 & 100 \\
\hline \multicolumn{7}{|l|}{ Usia ayah } \\
\hline 20-30 tahun & 30 & 33,7 & 59 & 66,3 & 89 & 100 \\
\hline $31-40$ tahun & 24 & 27,3 & 64 & 72,7 & 88 & 100 \\
\hline$>40$ tahun & 3 & 23,1 & 10 & 76,9 & 13 & 100 \\
\hline \multicolumn{7}{|l|}{ Pendidikan ayah } \\
\hline Rendah & 17 & 31,5 & 37 & 68,5 & 54 & 100 \\
\hline Tinggi & 40 & 29,4 & 96 & 70,6 & 136 & 100 \\
\hline \multicolumn{7}{|l|}{ Pekerjaan ayah } \\
\hline Bekerja & 57 & 30.2 & 1321 & 69,8 & 189 & 100 \\
\hline Tidak bekerja & 0 & 0 & & 100 & 1 & 100 \\
\hline
\end{tabular}

Tabel 2. Distribusi frekuensi baduta berdasarkan $\operatorname{BBLR}(n=190)$

\begin{tabular}{lcc}
\hline BBLR & Jumlah (n) & Persentase(\%) \\
\hline BBLR & 46 & 24,2 \\
Normal & 144 & 75,8 \\
Jumlah & 190 & $\mathbf{1 0 0}$ \\
\hline
\end{tabular}

Tabel 3. Distribusi frekuensi baduta kejadian stunting $(\mathrm{n}=190)$

\begin{tabular}{lcc}
\hline Stunting & Jumlah (n) & Persentase(\%) \\
\hline Stunting & 58 & 30,5 \\
Normal & 132 & 69,5 \\
\hline \multicolumn{1}{c}{ Jumlah } & $\mathbf{1 9 0}$ & $\mathbf{1 0 0}$ \\
\hline
\end{tabular}

termasuk kategori BBLR sebanyak 46 baduta $(24,2 \%)$.

Berdasarkan Tabel 3, anak di Kecamatan Sedayu Kabupaten Bantul baduta yang mengalami 
Tabel 4. Hubungan berat badan lahir rendah dengan kejadian stunting pada anak usia 6-23 bulan di Kecamatan Sedayu Kabupaten Bantul Yogyakarta

\begin{tabular}{cccccc}
\hline \multirow{2}{*}{ BBLR } & \multicolumn{2}{c}{ Kejadian stunting } & & $\begin{array}{c}\text { OR } \\
\text { (CI 95\%) }\end{array}$ & $\mathbf{p}$ \\
\cline { 2 - 3 } & Normal & Tidak stunting & Total & & \\
\hline BBLR & 28 & 18 & 46 & 6,16 & \\
& $(60,9 \%)$ & $(39,1 \%)$ & & $(3,007-$ & 0,000 \\
Normal & 29 & 115 & 144 & $12,656)$ & \\
& $(20,1 \%)$ & $(79,9 \%)$ & & & \\
Total & $\mathbf{1 0 0 \%}$ & $\mathbf{1 0 0 \%}$ & $\mathbf{1 9 0}$ & & \\
\hline
\end{tabular}

kejadian stunting sebanyak 58 responden $(30,5 \%)$

Pada Tabel 4 dapat dilihat bahwa responden yang BBLR mengalami stunting sebanyak 28 reponden $(60,9 \%)$, sedangkan responden yang lahir normal yang tidak mengalami stunting sebanyak 29 responden $(20,1 \%)$. Penelitian ini juga menggambarkan bahwa BBLR dinyatakan berhubungan secara signifikan dengan kejadian stunting yang ditunjukkan dengan hasil uji statistik diperoleh nilai $p 0,000(p<0,05)$ dan besar nilai odds rasio yaitu 6,16 . Hal ini menunjukkan bahwa baduta dengan berat badan lahir rendah kemungkinan 6,16 kali lebih berisiko untuk mengalami stunting pada anak atau probabilitas responden dalam kategori BBLR untuk mengalami stunting sebesar $60,9 \%$.

\section{PEMBAHASAN}

Hasil penelitian yang dilakukan di Kecamatan Sedayu Kabupaten Bantul terdapat 190 anak usia 6-23 bulan mayoritas berjenis kelamin laki-laki yaitu sebanyak 113 responden (59,5\%), sedangkan baduta yang berjenis kelamin perempuan sebayak 77 baduta $(40,5 \%)$ (Tabel 1). Jenis kelamin menentukan besarnya kebutuhan bagi seseorang sehingga terdapat keterkaitan antara status gizi dan jenis kelamin. Hasil penelitian juga menunjukkan bahwa persentase kejadian stunting lebih besar pada kelompok responden dengan jenis kelamin perempuan yaitu sebayak $(35,1 \%)$ (Tabel 1). Besar kebutuhan gizi tersebut dipengaruhi oleh adanya perbedaan komposisi tubuh antara laki-laki dengan perempuan (10).

Pada tahun pertama kehidupan, laki-laki lebih rentan mengalami malnutrisi daripada perempuan.
Hal ini disebabkan ukuran tubuh laki-laki lebih besar dan membutuhkan asupan energi lebih besar pula sehingga asupan makan tidak terpenuhi dan kondisi tersebut terjadi dalam jangka waktu lama dapat meningkatkan gangguan pertumbuhan. Pada tahun kedua kehidupan, perempuan lebih berisiko menjadi stunting. Hal ini terkait dengan pola asuh orang tua dalam memberikan makanan pada anak. Pada kondisi lingkungan dan gizi yang baik, pola pertumbuhan anak laki-laki lebih baik daripada anak perempuan. Anak perempuan dianggap sebagai anak yang lemah sehingga mendapatkan perhatian lebih dari orang tua dibandingkan dengan anak lakilaki yang lebih kuat (12).

Berdasarkan karakteristik usia orang menurut penelitian yang dilakukan di Desa Kodang, Kabupaten Tangerang Provinsi Banten, tingginya kategori kelahiran BBLR disebabkan oleh beberapa faktor antara lain umur ibu dan pekerjaan ibu. Pada lokasi penelitian tersebut banyak terdapat wanita yang menikah di bawah usia 20 tahun dan melahirkan anak. Kehamilan yang terjadi pada usia di bawah 20 tahun memiliki kecenderungan tidak terpenuhinya kebutuhan gizi yang adekuat untuk pertumbuhan janin yang akan berdampak terhadap BBLR (13). Wanita di bawah 20 tahun masih berada dalam tahap pertumbuhan dan perkembangan, sehingga kondisi hamil akan membuat dirinya harus berbagi dalam janin yang sedang dikandung untuk memenuhi kebutuhan gizinya. Sebaliknya, ibu yang berumur lebih dari 35 tahun mulai menunjukkan proses penuaannya, seperti sering muncul penyakit hipertensi dan diabetes mellitus yang dapat menghambat masuknya makanan janin melalui plasenta (13).

Berdasarkan Tabel 1, pada karakteristik pendidikan orang tua ibu menunjukan bahwa 
persentase stunting lebih tinggi pada kelompok ibu berpendidikan rendah yaitu sebayak $30,4 \%$. pada pendidikan ayah, persentase stunting terdapat lebih tinggi pada kelompok ayah berpendidikan rendah yaitu sebanyak $31,5 \%$. Hal ini sejalan dengan penelitian yang dilakukan Pormes, yang menunjukkan adanya hubungan antara pengetahuan orang tua tentang gizi dengan kejadian stunting pada anak usia 4-5 tahun $(p=0,000)(14)$. Pengetahuan tentang gizi pada orang tua dipengaruhi oleh beberapa faktor di antaranya adalah umur. Semakin tua umur seseorang maka proses perkembangan mentalnya menjadi baik, intelegensi atau kemampuan untuk belajar dan berpikir abstrak guna, menyesuaikan diri dalam situasi baru, kemudian lingkungan tempat seseorang dapat mempelajari hal-hal baik juga buruk tergantung pada sifat kelompoknya, budaya yang memegang peran penting dalam pengetahuan, pendidikan merupakan hal yang mendasar untuk mengembangkan pengetahuan, dan pengalaman yang merupakan guru terbaik dalam mengasah pengetahuan (15).

Berdasarkan Tabel 1, Karakteristik pekerjaan orang tua menunjukkan bahwa persentase stunting terdapat pada kelompok ibu responden tidak bekerja atau berprofesi sebagai ibu rumah tangga (IRT) yaitu sebanyak $31,6 \%$, sedangkan ayah responden memiliki pekerjaan yaitu sebanyak $30,2 \%$. Ibu lebih berperan dalam proses pengasuhan anak karena secara umum ayah berperan sebagai kepala rumah tangga dan bertugas untuk mencari nafkah serta memenuhi kebutuhan keluarga, sedangkan ibu berperan penting dalam pengurusan anak dan rumah tangga. Ibu yang tidak bekerja akan mempunyai waktu yang lebih banyak dengan anaknya dan mempengaruhi peningkatan kualitas gizi anaknya. Namun hasil penelitian ini menunjukkan bahwa persentase stunting sebagian besar terdapat pada ibu yang tidak bekerja (IRT) dan memiliki suami yang kerja sebagai buruh, sehingga dapat ditarik kesimpulan ada faktor lain yang menyebabkan anak mengalami stunting. Faktor tersebut di antaranya status ekonomi keluarga tidak terpenuhi sehingga mempengaruhi pendapatan keluarga yang akan berdampak langsung pada pemenuhan nutrisi.

\section{BBLR}

Berat badan lahir dapat menjadi indikator untuk melihat kemungkinan kelangsungan hidup, pertumbuhan, kesehatan jangka panjang, dan perkembangan psikologis anak. Penilaian status gizi secara antropometri pada bayi baru lahir dengan mengukur berat badan, panjang badan bayi, lingkar lengan atas, lingkar kepala adalah metode gizi untuk mengkaji bayi baru lahir yang sangat berpengaruh pada morbiditas dan mortalitas bayi pada umur selanjutnya (16). Hasil penelitian yang dilakukan menunjukkan terdapat 190 responden, yang megalami BBLR sebanyak 46 responden $(24,2 \%)$, sedangkan responden yang lahir normal sebanyak 144 responden $(75,8 \%)$. Angka kejadian stunting di Kecamatan Sedayu Kabupaten Bantul 24,2\% lebih rendah dibandingkan dengan angka kejadian BBLR di Desa Kodang Kabupaten Tangerang Banten yaitu sebayak 65,6\% (13) Tabel 2.

\section{Kejadian stunting}

Stunting merupakan suatu keadaan tinggi badan anak yang terlalu rendah. Stunting atau terlalu pendek berdasarkan umur adalah tinggi badan yang berada di bawah minus dua standar deviasi (<-2SD) dari tabel status gizi WHO child growth standard (17). Stunting pada balita merupakan hasil jangka panjang konsumsi kronik diet berkualitas rendah yang dikombinasikan dengan morbiditas, penyakit infeksi, dan masalah lingkungan. Hasil penelitian yang dilakukan didapatkan bahwa responden yang mengalami stunting sebanyak 58 responden $(30,5 \%)$ dan tidak mengalami stunting sebanyak 132 responden. Hasil penelitian ini tidak sejalan dengan penelitian Agustina dengan hasil bahwa sebagian besar responden mengalami stunting yaitu sebanyak 61 responden $(56,4 \%)$ dan tidak mengalami stunting sebanyak 51 responden $(43,6 \%)$

(18) Tabel 3.

\section{Hubungan BBLR dengan kejadian stunting}

Tabel 4 menunjukkan bahwa kejadian BBLR merupakan indikator kesehatan masyarakat karena erat hubungannya dengan angka kematian, kesakitan, kejadian kurang gizi di kemudian hari, salah satunya adalah status gizi pendek/stunting 
(10). Hasil penelitian ini menggambarkan bahwa responden yang mengalami stunting berasal dari responden yang BBLR, sedangkan responden yang tidak mengalami stunting adalah responden yang kategori normal (tidak BBLR).

Hasil penelitian ini juga menggambarkan bahwa BBLR dinyatakan berhubungan secara statistik dengan kejadian stunting pada anak usia 6-23 bulan yang ditunjukkan dengan hasil uji statistik chi-square diperoleh nilai $p 0,000(p<0,05)$, sehingga dapat disimpulkan bahwa ada hubungan antara berat badan lahir rendah dengan kejadian stunting pada anak usia 6-23 bulan di Kecamatan Sedayu Kabupaten Bantul Yogyakarta. Akan tetapi odds rasio pada penelitian ini menunjukkan nilai sebesar 6,16 yang menunjukkan bahwa responden yang mengalami berat badan lahir rendah sangat berisiko untuk mengalami stunting.

Hal ini sejalan dengan penelitian Rahayu et al., dengan hasil analisis bivariat menunjukkan bahwa terdapat hubungan yang signifikan antara riwayat status BBLR dengan stunting pada baduta $(p=0,015)$. Berdasarkan hasil analisis multivariat, diperoleh bahwa BBLR merupakan faktor risiko yang paling dominan berhubungan dengan kejadian stunting. Anak dengan BBLR memiliki risiko 5,87 kali untuk mengalami stunting di wilayah Puskesmas Sungai Karias, Hulu, Sungai Utara (19). Hasil ini juga sejalan dengan penelitian oleh Paramashanti et al., bahwa di Indonesia anak yang lahir dengan berat badan lahir rendah (BBLR) memiliki risiko yang lebih tinggi untuk menjadi anak yang stunting $(\mathrm{OR}=1,77$; Cl: 1,33-2,37) (20). Hasil dari penelitian Lestari, W, dkk di Aceh juga menunjukkan bahwa bayi dengan BBLR berisiko untuk mengalami stunting hingga 3,26 kali lebih besar dibandingan bayi tanpa riwayat BBLR (OR $=3,26,95 \% \mathrm{Cl}: 1,46-7,31)$.

Bayi BBLR tipe kecil masa kehamilan (dismatur), sejak dalam kandungan telah mengalami retardasi pertumbuhan interauterin dan akan berlajut sampai usia selanjutnya setelah dilahirkan yaitu mengalami pertumbuhan dan perkembangan yang lebih lambat dari bayi yang dilahirkan normal, dan sering gagal menyusul tingkat pertumbuhan yang seharusnya diacapai pada usia setelah lahir (7). Hambatan pertumbuhan yang terjadi berkaitan dengan maturitas otak, dimana sebelum usia kehamilan 20 minggu terjadi hambatan pertumbuhan otak seperti perubahan somatik (8).

\section{Keterbatasan dan Hambatan Penelitian}

Hambatan dalam penelitian ini yaitu adanya kesulitan dalam proses pengambilan data karena penelitian harus dilakukan dirumah responden yang jaraknya cukup berjauhan dengan jumlah sampel 190 responden, sehingga membutuhkan waktu yang cukup lama untuk memperoleh data dari responden.

Kekurangan penelitian cross-sectional yang pertama adalah sulit untuk menentukan sebab akibat karena pengambilan data risiko dan efektif dilakukan dalam waktu yang bersamaan (temporar relationship tidak jelas). Kedua studi prevalensi lebih banyak menjaring subjek yang mempunyai masa sakit yang panjang dari pada mereka yang mempunyai masa sakit yang pendek. Terakhir penelitian cross sectional tidak mengambarkan perjalanan pejalanan penyakit, insidens, maupun prognosis (21).

\section{KESIMPULAN DAN SARAN}

BBLR berhubungan dengan kejadian stunting pada anak usia 6-23 bulan di Kecamatan Sedayu Kabupaten Bantul Yogyakarta. Anak dengan riwayat kelahiran BBLR mepunyai risiko 6,16 kali lebih besar untuk mengalami stunting dibandingkan dengan anak riwayat kelahiran normal.

Kepada para tenaga kesehatan terkhusus tenaga kesehatan yang berada di Kecamatan Sedayu kabupaten Bantul Yogyakarta diharapkan untuk melakukan pemantauan status gizi dan selama hamil perlu dilakukan lebih intensif untuk mencegah terjadi BBLR. Hal ini dapat dilakukan dengan mengadakan kegiatan kunjungan rumah terhadap ibu hamil yang tidak rutin kepelayanan kesehatan, serta memberi motivasi dan konseling kepada ibu agar menjalani kehamilan yang sehat sehingga akan melahirkan bayi dengan berat badan lahir normal (BBLN).

Bagi Dinas Kesehatan perlu adanya pemantauan terus menerus terhadap pertumbuhan anak baik sejak masa bayi dan balita sehingga program intervensi yang akan diberikan dapat direncanakan sebelumnya dan dapat lebih efektif. 


\section{RUJUKAN}

1. Al-Anshori $\mathrm{H}$, Nuryanto $\mathrm{N}$. Faktor risiko kejadian stunting pada anak usia 12-24 bulan (Studi di Kecamatan Semarang Timur) [Internet]. Universitas Diponegoro; 2013 [cited 2015 Aug 7]. Available from: http://eprints.undip. ac.id/41855/

2. United Nations Children's Fund (UNICEF). Tracking progress on child and maternal nutrition: A survival and development priority [Internet]. New York: United Nations Children's Fund (UNICEF); 2009 [cited 2016 Jun 3]. Available from: https://www.unicef.org/publications/files/ Tracking_Progress_on_Child_and_Maternal_ Nutrition_EN_110309.pdf

3. Badan Penelitian Dan Pengembangan Kesehatan Kementerian Kesehatan RI. Riset kesehatan dasar Riskesdas 2013. Jakarta: Balai Penelitian Dan Pengembangan Kesehatan RI; 2013.

4. Dinas Kesehatan Kabupaten bantul. Profil kesehatan kabupaten Bantul 2012 [Internet]. Yogyakarta: Dinkes Bantul; 2012 [cited 2015 Oct 27]. Available from: https://www.scribd.com/ doc/176550712/Profil-Bantul-2012

5. Nasution D, Nurdiati DS. Hubungan berat badan lahir rendah (BBLR) dengan kejadian stunting pada anak usia 6-24 bulan di Kota Yogyakarta. Universitas Gadjah Mada; 2014.

6. Dinas Kesehatan Provinsi D.I.Yogyakarta. Profil kesehatan Provinsi D.I.Yogyakarta tahun 2008. Yogyakarta: Dinas Kesehatan Provinsi D.I.Yogyakarta; 2009.

7. Proverawati A, Cahyo IS. BBLR: Berat Badan Lahir Rendah. Yogyakarta: Nuha Medika; 2010.

8. Meadow SR, Newell SJ. Lectures notes pediatrika. Jakarta: Erlangga; 2005.

9. Lestari W, Margawati A, Rahfiludin Z. Faktor risiko stunting pada anak umur 6-24 bulan di kecamatan Penanggalan ota Subulussalam provinsi Aceh. J GIZI Indones [Internet]. 2014 [cited 2016 Jun 7];3(1):37-45. Available from: http://ejournal.undip.ac.id/index.php/jgi/article/ view/8752
10. Cakrawati D, NH M. Bahan Pangan, Gizi, Dan Kesehatan. Bandung: Alfabeta; 2014.

11. World Health Organization. WHO Child Growth Standards, WHO Child Growth Standards 1 year 2 years 3 years 4 years 5 years,Length/ height-for-age, weight-for-age, weight-forlength, weight-for-height and body mass indexfor-age, Methods and development [Internet]. Switzerland; 2006 [cited 2016 Aug 8]. Available from: http://www.who.int/childgrowth/standards/ Technical_report.pdf?ua=1

12. Gershwin ME, Nestel P, Keen CL. Handbook of Nutrition and Immunity. New Jersey: humana press; 2004.

13. Rahayu LS. Hubungan pendidikan orang tua dengan perubahan status stunting dari usia 6-12 bulan ke usia 3-4 tahun. Proseding Penelitian Bidang IImu Eksakta 2011 [Internet]. Jakarta: University of Universitas Muhammadiyah Prof. Dr. Hamka, Jakarta; 2011 [cited 2016 May 6]. Available from: http://lemlit.uhamka.ac.id/files/ makalah7leni.pdf

14. Pormes WE, Rompas S, Ismanto AY. Hubungan pengetahuan orang tua tentang gizi dengan stunting pada anak usia 4-5 tahun di TK Malaekat Pelindung Manado. JKEPERAWATAN. 2014;2(2).

15. Notoatmodjo S. Metodologi penelitian kesehatan. Jakarta: Rineka Cipta; 2010.

16. Irawati A, Salimar D. Status gizi ibu sebelum hamil sebagai prediksi berat dan panjang bayi lahir di Kecamatan Bogor Tengah, Kota Bogor: studi kohor prospektif tumbuh kembang anak tahun 2012 -2013 (Pre-pregnancy maternal nutritional status as a predictor of birth weight and le. Penel Gizi Makan. 2014;37(2):119-28.

17. World Health Organization. Interpretation Guide Nutrition Landscape Information System (NLIS). Switzerland: WHO Press; 2010.

18. Agustina. Amanda. Faktor-faktor resiko kejadian stunting pada balita (24-59 bulan) di wilayah kerja Puskesmas Sosial Palembang 2014. Universitas Sriwijaya; 2015.

19. Rahayu A, Yulidasari F, Putri AO, Rahman F. Riwayat Berat Badan Lahir dengan Kejadian Stunting pada Anak Usia Bawah Dua Tahun. 
Kesmas Natl Public Heal J. 2015 Nov 8;10(2):6773.

20. Paramashanti BA, Hadi H, Gunawan IMA. Pemberian ASI eksklusif tidak berhubungan dengan stunting pada anak usia 6-23 bulan di
Indonesia. J Gizi dan Diet Indones (Indonesian J Nutr Diet. 2016 Aug 29;3(3):162-74.

21. Sastroasmoro S. Dasar- dasar metodologi penelitian klinis. Jakarta: Binarupa Aksara; 1995. 